\title{
Elizabeth Mavroudi and Caroline Nagel, Global Migration: Patterns, Processes, and Politics
}

Routledge, London, 2016, pp. 242

The book Global Migration: Patterns, Processes, and Politics by Elizabeth Mavroudi and Caroline Nagel has the potential to become a new classic textbook used by scholars and students of international migration alike. The book makes the case for the complexity of global migration and presents many ambiguities surrounding the issue. Scholarly as well as hands-on, it is an interesting read from the first page (it begins by describing the protests against immigration in Tel Aviv in 2012). The book brings fresh perspectives from the current research on migration and clusters them in general themes that can be used in a university setting as well as by anyone who wants to learn more about the intricacies of global movements of people. The book systematizes the topics and links them in a logical way, often cross-referencing between different chapters. Mavroudi and Nagel offer countless interesting case studies, but in the end they concede that "embracing the messiness of migration, then, is not about miring ourselves in the details of every single migration case study" (p. 225). However, it is the specific cases that make their arguments persuasive. The authors do an excellent job presenting the scale of the phenomenon of international migration and its centrality in the current world, regardless of the geographic setting.

Elizabeth Mavroudi is a lecturer in human geography at Loughborough University, UK and Caroline Nagel is an associate professor of geography at the University of South Carolina, USA. Even though the book is multidisciplinary, it is firmly grounded in the social sciences. The added value of the book comes from drawing on the tradition of migration studies from their respective countries and presenting a coherent account of the migration narratives in the transatlantic space. Therefore, it does not fall in the trap of being too country-specific, while still managing to acquaint the readers with the main debates in migration studies. The authors do not shy away from presenting themes that are connected to the Global South and using lesser known examples. By the same token, critical approaches such as race and gender which are used to problematize the dominant discourses are incorporated in the book. One salient aspect of this work is migrant agency, which is highlighted throughout the work and especially in its concluding chapter (Migrant identities, mobilizations, and place-making practices). This final part offers a more migrant-centred perspective and tries to explore how the migrants negotiate their identities, spaces or politics. The interplay between agency and structure, as well as their potential friction, is explored from the beginning.

The book covers a lot of ground and can serve as an overview of various topics pertaining to migration literature, with a comprehensive list of further reading and references at the end of each chapter. In total, the book comprises eight chapters with the first and the last serving as an introduction and conclusion. The chapters cover global historical perspectives on migration, migrant labour in the economy, migration and development, refugees, border politics and the politics of citizenship and integration. Theoretical perspectives on international migration are briefly mentioned in the introductory chapter Making sense of global migration, right after the definitions and an explanation of why global migration matters, but more space could be dedicated to them. The concepts of transnationalism and diaspora that have become increasingly important in the past two 
decades of migration research are incorporated at various places throughout the book but they are not given a separate section except for the very end of the book.

The subheadings in the title of the book - Patterns, Processes, and Politics - are not accidental, as they are tackled throughout the book in the same order. The beginning of the book deals with historical patterns of migration, or as the authors put it, "who moves and who doesn't move, where they go and why" (p. 28). The authors want to highlight the universality of some of the migration patterns while bearing in mind the specifics of the individual cases. Migration processes follow the plethora of political, economic and social dynamics shaping migration, which are explored in the central part of the book. The authors acknowledge the simultaneity of different kinds of migrations and their interconnectedness. Finally, the politics of migration, attempts by nation-states to regulate migration and the ways in which migrants respond to them are covered towards the end of the book.

The chapter Global migration in historical perspective spans the period from the emergence of the modern state system to the $20^{\text {th }}$ century. It covers not only the European-centred world economy, including the slave trade and indentured labour, but also focuses on non-European societies and their power relations. After covering the processes of industrialization and urbanization, it proceeds to discuss the upheavals of the $20^{\text {th }}$ century. This is followed by a section describing migration to the emerging economies, recalling that in the early $20^{\text {th }}$ century Japan was an important imperial power which relied on Korean labour. The next chapter Migrant labour in the economy discusses migrant participation in the labour market and the mechanisms through which migrants can be included or excluded in particular occupations and sectors. This chapter balances the role of employers, state and societal norms as well as the migrants' participation in the economies, and presents the concepts of deskilling, labour market segmentation and middleman minority. The chapter on Migration and development explores the migration-development nexus and focuses on the ways lack of development fosters emigration and how emigration may in turn contribute to development. The chapter on Refugees compares the politics of refuge and asylum in the Global North and the Global South and the ways in which refugees respond to the efforts of the states and humanitarian organizations to "manage" them. The final two chapters on Immigration control and border politics and The politics of citizenship and integration deal with the topics of state power over mobility, securitization of migration and the dynamics through which immigrant-receiving societies define who belongs. The discussion takes the migrant perspective into account and shows that at times they can politically mobilize and claim inclusion in the national narratives.

When not looking at the individual scale, the main focus is on the countries of destination. This perspective briefly shifts to the sending societies in Chapter Four, focusing on migration and development, before it swings back to the receiving states. The second part of the book scrutinizes the role of the international human rights regime in refugee protection (and whether the current refugee regime is sufficient or how it could be changed) and state-level policies regulating migration. Finally, the book focuses on the ways in which migrants are incorporated into the receiving societies and how distinctions are created between immigrants and citizens. Some recent trends are also noted, including the difficulties in accessing naturalization and the tightening of the migration regimes in the states of the Global North. The authors point out various ambiguities concerning some 
aspects of policies geared towards greater inclusion while at the same time reinforcing the exclusion of immigrants.

The book features several interesting case studies. One of them focuses on the formation of ghettos. Residential segregation has been a scholarly focus for many years. For example, the works on Jewish ghettoes in Chicago as well as Vancouver's Chinatown offer an analysis of the ways in which ghettoes are perceived by the dominant groups. While ghettoes elicit anxieties amongst the mainstream society, scholars have tried to amend the misrepresentations of these spaces and show what does and does not constitute a ghetto. They have thereby dispelled the myth of their neat existence and showed that the formation of a ghetto is very rare.

Another case study follows the journey of the Uighurs from China to Saudi Arabia and back. After being expelled in the 1960s, they were allowed to re-enter China in the following decades. The Uighurs were still able to travel to Saudi Arabia and thus gained exposure to the form of Islam practiced there. This was seen as encouraging separatism in Xinjiang, ushering in another wave of state repression in China. Some unlikely countries became entangled in this situation as some radicals were captured during the American invasion of Afghanistan. After a long period of detention, the USA did not want to admit them (and they could not be sent back to China on the grounds of possible human rights violations) so they had to be resettled in Slovakia and Albania, among other countries.

The book includes a large amount of visually appealing graphic materials, including photos, figures and tables. The text also includes box inserts which offer in-depth explanations of various concepts and terminology (from "Japanese imperialism and Korean immigration" to "Frontex"). Some of the photos are recent, especially the ones referring to the migration situation in Europe in 2015. Apart from the pictures, one interesting figure is a copy of a sample contract signed by Filipino domestic workers going to work abroad (p. 68). According to the contract, "the man/woman worker should be ready at all times day and night; no hours assigned for rest except for sleeping, eating or praying." Examples such as this make the book exceptionally down-to-earth, tangible and humane.

Overall, the book can serve as a valuable source of information for classroom use and can be used as introductory material for anyone wishing to identify important clusters of research on various global migration issues. It will also not disappoint more well-versed migration scholars, as most of the influential results of recent research are discussed. Moreover, the book can provide valuable resources to inform anyone's teaching and lesson plans. Global Migration: Patterns, Processes, and Politics is a holistic book offering various perspectives on international migration and no simple prefabricated answers. This is a good thing, as the authors wish to give the readers "the wherewithal to engage critically with public discourses and to participate meaningfully and constructively in political debates on immigration" (p. 24). For careful readers, this should not be a problem.

Lucie Mackova 